\title{
The ghost mammals from Mexico and their implications
}

\author{
Alina Gabriela Monroy-Gamboa ${ }^{1 *}$ \\ ${ }^{1}$ Centro de Investigaciones Biológicas del Noroeste, S. C. Av. Instituto Politécnico Nacional 195, Playa Palo de Santa Rita Sur, 23096, \\ La Paz, Baja California Sur, México. Email: beu ribetzin@hotmail.com \\ *Corresponding author
}

The species records are key to determine their distribution. In México, there are records located up to more 200 km outside the known range of Ateles geoffroyi, Cryptotis mayensis, Pteronotus davyi and Tlacuatzin sinaloae. Other species were captured in their type locality but have not been recorded again over up to 100 years: Dipodomys gravipes, Oryzomys peninsulae, Peromyscus mekisturus, P. pembertoni, Sorex sclateri, S. stizodon, Tylomys bullaris and T. tumbalensis. This study analyzes these mammalian species records, their information gaps related with their known range, and discusses the likely implications for conservation. A survey of the literature and databases of scientific collections available on the Internet were conducted. A geographic information system was used for the spatial analysis of the records obtained. Records outside the limit of the known range of these species are due to misidentification of specimens, accidental introduction and lack of field corroboration. Some of the species captured only in their type locality can be deemed extinct while others require field and laboratory work. Geographic records of the species are valuable inputs to define the distribution range of species and advance our current knowledge about the Mexican. The use of records with errors or that should no longer be considered have an impact on the risk categorization of species and the development of conservation strategies.

Los registros de especies son importantes para conocer su distribución geográfica. En México, hay especies con registros fuera de su área de distribución conocida hasta por más de 200 km: Ateles geoffroyi, Cryptotis mayensis, Pteronotus davyi y Tlacuatzin sinaloae. Otras se capturaron en su localidad tipo y no se han vuelto a registrar hasta por 100 años: Dipodomys gravipes, Oryzomys peninsulae, Peromyscus mekisturus, $P$. pembertoni, Sorex sclateri, S. stizodon, Tylomys bullaris y T. tumbalensis. El objetivo de este trabajo es analizar los registros de estas especies de mamíferos, sus vacíos de información en relación con su área de distribución conocida, así como las posibles implicaciones que conllevan para la conservación. Se realizó una consulta bibliográfica y de bases de datos de colecciones científicas disponibles en internet. Se usó un sistema de información geográfica para el análisis espacial de los registros obtenidos. Los registros encontrados muy fuera del límite de la distribución conocida de estas especies, se deben a identificación errónea de los ejemplares, introducción accidental y falta de corroboración en campo. Mientras que las especies que solo se han capturado en su localidad tipo, algunas pueden considerarse extintas y otras más requieren trabajo de campo y laboratorio. Los registros geográficos de las especies son información importante para definir la distribución de las especies y de esta manera robustecer el conocimiento que se tiene sobre la biodiversidad mexicana. El uso de registros, con errores no deben ser considerados, debido a que repercuten en la categorización riesgo de las especies y por ende las estrategias de conservación.

Keywords: Conservation; extinction; geographic distribution range; records; systematics; taxonomy.

C 2021 Asociación Mexicana de Mastozoología, www.mastozoologiamexicana.org

\section{Introduction}

Records of wild species are essential to determine their geographic distribution through the reconstruction of biodiversity from historical times (fossil records) to the present. These records can be consulted by searching literature reports or databases of scientific collections, many of them are already digitalizated and are available at Internet in many platforms. Some of these platforms are fed by records from citizen observations, and experts validate the identifications of the species, like NaturaLista (https:// www.naturalista.mx/), but sometimes the photographs do not show accurate characteristics in order to identified them correctly. Today, the use of scientific collection databases is increasingly common in research because of the convenience and low cost of obtaining these data. By combining them with environmental variables, known distribution ranges, and ecological and evolutionary aspects of species, they can be used for the management, use, and conservation of species and their ecosystems (Graham et al. 2004; Funk 2018; Cook and Light 2019).
In México, several mammal species were collected once at a certain time and place and were never observed or collected again, it means they are unique records. This can be potentially caused by two scenarios: records outside the known range of the species and unique records from type localities that have not recorded again over up to 100 years. The first involves species with a broad range that have any record on the literature or in scientific collections databases completely outside their known range, with large areas between them. This is the case of the Spider monkey (Ateles geoffroyi), recorded $10 \mathrm{~km}$ NNW of Cihuatlán, Jalisco and 25 km NNW of Ciudad Victoria, Tamaulipas (Villa 1958). Yucatán small-eared shrew (Cryptotis mayensis), family Soricidae, collected at Cueva del Cañón del Zopilote, Guerrero (Choate 1970). Davy's naked-backed bat (Pteronotus davyi), family Mormoopidae, collected at Cueva de los Mártires, Sierra La Laguna, Southern Baja California Sur (Woloszyn and Woloszyn 1982). The grayish mouse opossum (Marmosa sp. [Tlacuatzin sinaloae sic]), family Didelphidae, collected at Misión de San Ignacio, Baja California Sur (LópezForment and Urbano 1977). 
The second regards endemic species with restricted distribution that were collected in the type locality when they were described but have not been recorded again for more than 100 years. This is the case of San Quintín kangaroo rat (Dipodomys gravipes) from San Quintín, Baja California; Lower California rice rat (Oryzomys peninsulae) from Santa Anita, Baja California Sur; Puebla deermouse (Peromyscus mekisturus) from Ciudad Serdán, Puebla; San Pedro Nolasco deermouse (Peromyscus pembertoni) from San Pedro Nolasco island, Sonora; Sclater's shrew (Sorex sclateri) and San Cristóbal shrew (Sorex stizodon) from San Cristóbal de las Casas, Chiapas. Chiapan climbing rat (Tylomys bullaris) from Tuxtla Gutiérrez, Chiapas; and Tumbalá climbing rat (Tylomys tumbalensis) from Tumbalá, Chiapas. Of these, $P$. pembertoni and O. peninsulae are considered extinct (Álvarez-Castañeda et al. 2017; DOF 2019).

The species records mentioned here, are used to produce lists of species for particular geographic areas, and also, their biological richness. Furthermore, the records are used to know the potential distribution of the species in a given area; in turn, this is a meaningful variable in determining the risk status of species as reflected in national and international regulations and laws (NOM-059-SEMARNAT-2010, Red List of the International Union for Conservation of Nature and the Endangered Species Act for the United States and Canada). Altogether, the species listings and proposed distribution have potential implications for the conservation, as well as for the creation and regulation of conservation, management, and utilization policies for the species from a given geographic area. If the information taken as input is incorrect, this will affect the whole approach proposed; so, it highlights the importance of the curatorship of scientific collections and the deposit of the specimens in them, in order to contribute for the verification of the records.

The analysis of the mammals of México commonly uses historical records of these species, although each of these records has been mentioned in recent publications and referencing the original work with no critical perspective on the relevance of these records or the permanence of the species.

This warrants a critical review of the 12 mammal species mentioned above, aiming to contribute to solve the questions regarding the knowledge of their distribution, ecology, biology and conservation. The objective of this study is to analyze the records, their information gaps related with the known range of these mammal species, and discuss the potential implications for the conservation of the geographic their area involved; even though they are records outside the known distribution range and unique records.

\section{Materials and Methods}

Literature references and databases of scientific collections were surveyed through VertNet (https://vertnet.org/), GBIF (https://www.gbif.org/), IBdata (https://www.ibdata. ib.unam.mx/web/), in addition to the Mammal Collection of Centro de Investigaciones Biológicas del Noroeste, S.C., to locate specimens collected in areas near the records of the localities of the species concerned: Ateles geoffroyi (Jalisco and Tamaulipas), Cryptotis mayensis (Guerrero), Pteronotus davyi (Baja California Sur) and Tlacuatzin sinaloae (Baja California Sur). The records were projected into the geographic space for measurements of distances between the outside of the known distribution range records and analyze them by a geographic information system with the software QGIS v.3.8.3 (QGIS 2018).

Also considered were species known only from the type locality, with a very limited number of specimens collected at least 100 years ago and for which no additional specimens have been recorded again after the original date of collection. For the above reason, information on ecology and biology is virtually unknown.

\section{Results}

Records outside the known distribution. Ateles geoffroyi was reported by sightings in two states outside its known distribution. In the state of Jalisco, a group of five individuals was observed on the road to Bahía de Navidad (currently Barra de Navidad; Figure 1A) in a tropical forest with Ficus sp. vegetation (Villa 1958). Villa (1958:346) states "I immediately got the idea that these animals may have escaped from the captivity of some transhumant circus or from the possession of local people; but the fact that they were found in an area of very small human population and that the few ranchers interviewed were not surprised by their presence, makes me think that they have been endemic in the region. I certainly do not know since when these animals have prowled the contours and I fear they will not persist for much longer". The closest confirmed record on the Pacific coast is located in Oaxaca at $1,045 \mathrm{~km}$ to the south, and on the Gulf of México slope, $781 \mathrm{~km}$ away in Veracruz (Table 1; GBIF 2021).

There are indications of the possible presence of Spider monkeys in Acapulco, Guerrero (Kellogg and Goldman 1944); in addition, this species was frequently used as pet in the 1960s, and there are accounts that monkeys were captured near Acapulco. Therefore, it is highly likely that some troops would have survived until that time (Juan Pablo Gallo-Reynoso, pers. comm.). The Spider monkey is also depicted in pre-Columbian representations such as vessels and stone engravings; there was even a ruler named "Gran Mono" (Great Monkey) in 1393. This suggests that the species inhabited localities of the state of Guerrero, such as La Sabana and Palma Sola in Acapulco, from pre-Columbian times to the colonial period, when it was recorded by Humboldt (Reyes-Álvarez and GuerreroGómez 2014). Its presence in these localities was not confirmed from records in scientific collections. There is a single record (1895613809 GBIF 2021) with geographic coordinates between the localities mentioned in Acapulco, but all other data correspond to a record of Goodwin (1969) in the state of Oaxaca; this case highlights the need to always review the complete set of data instead of 
only considering the species and geographic coordinates reported, as the error may lie in how the locality was georeferenced.

In case the Spider monkey is considered to be present in Acapulco, the Jalisco record is still $567 \mathrm{~km}$ away (Table 1). Two additional factors are key for ruling out the presence of Ateles geoffroyi in the state of Jalisco. The first is the Balsas basin and river, which is an insurmountable barrier for Spider monkeys because of their ethology of aversion of open areas; the second is the lack of continuous vegetation that would allow the survival of this species throughout the year (González-Zamora et al. 2009). It results feasable that the Spider monkey population referred to Jalisco (Villa 1958) in fact, was a circus or pet release, when people can not mantain the animals anymore, they release them in a place that they think is optimal for their subsistance.

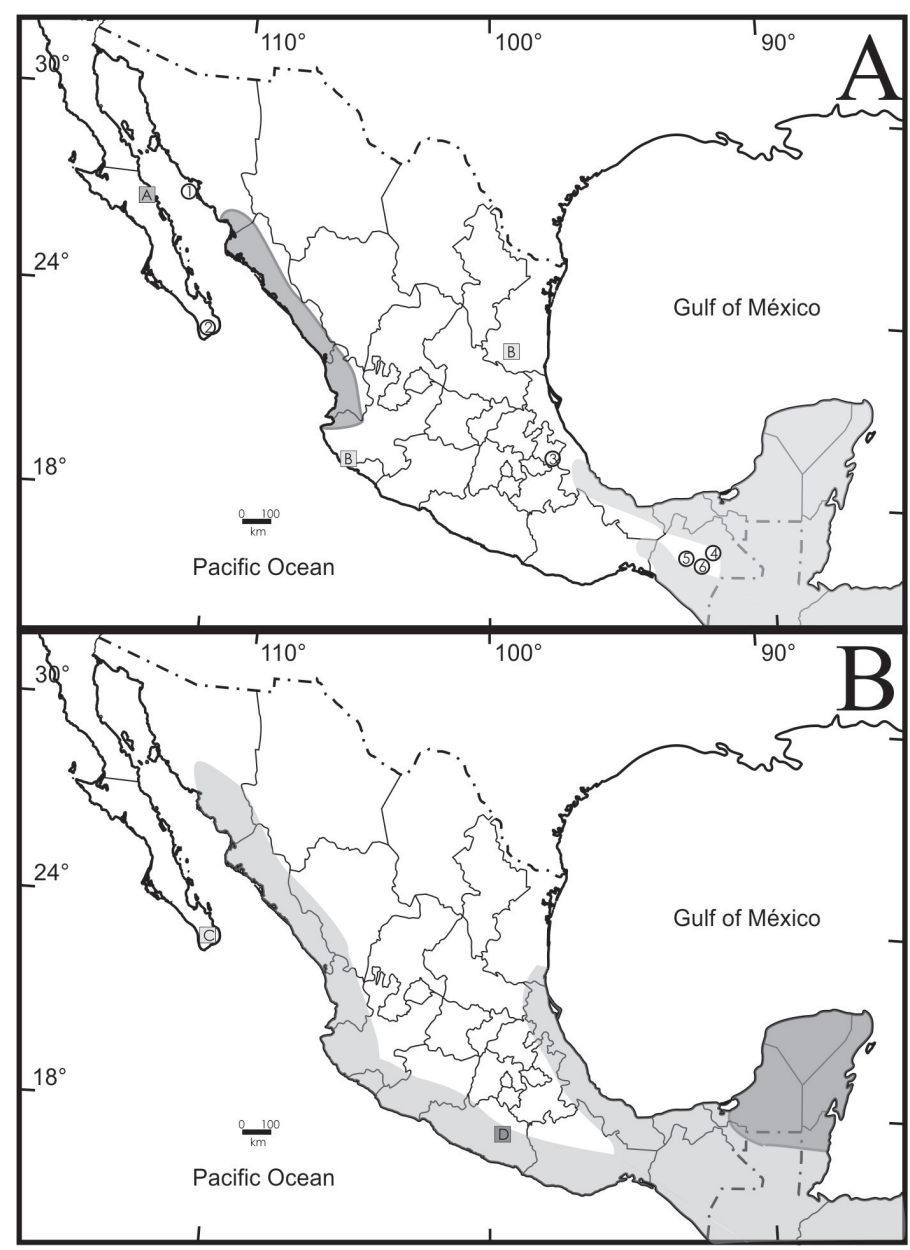

Figure 1. Map showing the distribution of species known only by the type locality. A. Dipodomys gravipes (1), Peromyscus pembertoni (2), Oryzomys peninsulae (3), Peromyscus mekisturus (4), Tylomys tumbalensis and Sorex stizodon (5), Tylomys bullaris (6) and Sorex sclateri (7). The current distribution of Ateles geoffroyi is shown in light gray; the boxes with the letter $A, B$ and $C$ mark the records outside its known range, the letter $D$ marks a possible distribution and the letters $E$ and $F$ show records from the known range. The current distribution of Tlacuatzin sinaloe is shown in dark gray; the box with the letter $L$ marks the record outside its known range and the letter $M$ shows a record from the known range. B. The current distribution of Cryptois mayensis is shown in dark gray; the boxes with the letter $\mathrm{G}$ marks the record outside its known range and the letters $\mathrm{H}$ and I show records from the known range. The current distribution of Pteronotus dayvi is shown in light grey; the box with the letter J marks the record outside its known range and the letter $\mathrm{K}$ show a record from the known range.
Ateles geoffroyi was also recorded in the vicinity of Ciudad Victoria, Tamaulipas (Villa 1958). In this record, Villa (1958) refers to it from a talk with Dr. Málaga Alba: "He informed me of another similar encounter, but in the highest portion of Barranca de Caballeros, approximately $25 \mathrm{~km}$ in straight line NNW of Ciudad Victoria, Tamaulipas, in 1954" (Villa 1958:347). However, this claim was never confirmed by the author, nor he was physically in the area to determine whether the type of habitat was appropriate for the presence of the species. Villa (1958) considered this account as valid based on the suggestion by Kellogg and Goldman (1944) that A. geoffroyi may inhabit the tropical forest in the southern region of the state, because in 1898, the northern limit of its distribution was San Luis Potosí, but these authors did not confirm this distribution. Subsequently, Álvarez (1963) mentioned that in addition to the account by Villa (1958) and the suggestion of Kellogg and Goldman (1944), no additional records are available, not even after having conducted fieldwork in the area.

Currently, the records available in the collection databases are those referred to in the literature (Villa 1958; Álvarez 1963). The linear distance between the Tamaulipas record to the nearest known record in the locality of Teocelo, Veracruz, is $781 \mathrm{~km}$ (Table 1).

There is another atypical record of Ateles geoffroyi in Ciudad Juárez, Chihuahua, corresponding to a male that was found dead in a waste lot; the skin and skull are deposited in the collection of the University of Texas at El Paso (UTEP 7964). This record most likely corresponds to a discarded corpse of a dead pet since the closest record of its known distribution is in Teocelo, Veracruz, at 1,657 km (Table 1).

The analysis of the three records of $A$. geoffroyi mentioned above coincides in that they are not located within the distribution range of the species and its habitat is also discontinuous; besides, individuals of this species are commonly kept as pets. Based on this, we consider that these records should not be used. Ateles geoffroyi is listed as Endangered in NOM-059-SEMARNAT-2010 (DOF 2019) and as Endangered category (A4cd: Population decline to observed levels of $30 \%$ or lower over ten years due to the decline in the distribution area, potential range, habitat quality, and actual exploitation levels) by IUCN (CortesOrtíz et al. 2021).

Cryptotis mayensis were recorded from remains (parts of skulls and mandibles) found in pellets of T. alba collected on 9 September 1969 (López-Forment and Urbano 1977; Figure 1B), deposited in the Colección Nacional de Mamíferos of the Instituto de Biología at Universidad Nacional Autónoma de México (CNMA 11031-11043 and 12666-12692; Choate 1970; Ramírez-Pulido and SánchezHernández 1972; Carraway 2007). The survey in VertNet and IBData yielded no records of $C$. mayensis in the state of Guerrero, with La Tuxpeña, Campeche, being the nearest locality at $1,013 \mathrm{~km}$ in a straight line (Table 1); however, this implies transiting through habitats that are not typical of the species. Should the species had dispersed through the 


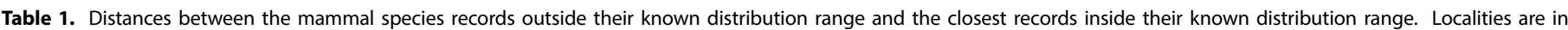
regerences to Figure 1

\begin{tabular}{|c|c|c|c|c|c|c|}
\hline Species & & Type of record & Georreference & Locality & Distance (km) & Reference \\
\hline \multirow[t]{6}{*}{ Ateles geoffroyi } & A & Out range & $31.7020,-106.4670$ & Ciudad Juárez, Chihuahua & $\mathrm{A} / \mathrm{E}=1,657$ & GBIF 2021 \\
\hline & B & Out range & $23.7361,-99.1461$ & Barranca de Caballeros, Ciudad Victoria, Tamaulipas & $B / E=512$ & Villa 1958 \\
\hline & $\mathrm{C}$ & Out range & $19.2255,-104.6501$ & Cihuatlán, Jalisco & $C / F=1,045$ & Villa 1958 \\
\hline & $\mathrm{D}$ & Possible range & $16.8668,-99.8206$ & Acapulco, Guerrero & $C / D=567$ & Reyes-Álvarez and Guerrero-Gómez 2014 \\
\hline & $\mathrm{E}$ & In range & $19.3916,-96.9750$ & Teocelo, Veracruz & & GBIF 2021 \\
\hline & $\mathrm{F}$ & In range & $16.3226,-95.2423$ & Tehuantepec, Oaxaca & & Hall 1981 \\
\hline \multirow[t]{3}{*}{ Cryptotis mayensis } & $\mathrm{G}$ & Out range & $17.1327,-99.6013$ & Cañón del Zopilote, Guerrero & $\mathrm{G} / \mathrm{H}=1,013$ & Ramírez-Pulido and Sánchez Hernández 1972 \\
\hline & $\mathrm{H}$ & In range & $18.4494,-90.1144$ & La Tuxpeña, Campeche & & GBIF 2021 \\
\hline & 1 & In range & $17.3936,-89.6336$ & Uaxactún, Guatemala & $\mathrm{G} / \mathrm{I}=1,206$ & GBIF 2021 \\
\hline \multirow[t]{2}{*}{ Pteronotus davyi } & J & Out range & $23.6533,-109.6908$ & Cueva de los Mártires, BCS & $\mathrm{J} / \mathrm{K}=232$ & Woloszyn and Woloszyn 1982 \\
\hline & $\mathrm{K}$ & In range & $24.9319,-107.8738$ & La Chinacatera, Sinaloa & & GBIF 2021 \\
\hline \multirow[t]{2}{*}{ Tlacuatzin sinaloae } & $\mathrm{L}$ & Out range & $27.2839,-112.8839$ & Misión de San Ignacio, BCS & $\mathrm{L} / \mathrm{M}=393$ & López-Forment and Urbano 1977 \\
\hline & M & In range & $27.0233,-108.9322$ & Álamos, Sonora & & GBIF 2021 \\
\hline
\end{tabular}

inhabits considered by the species records implies a dispersion through the Isthmus of Tehuantepec, coast of Chiapas, Oaxaca and Guerrero of approximately 1,206 km to reach the nearest locality by this route in Uaxactún, Petén in Guatemala (Table 1).

Choate (1970:270-277) analyzed the referred specimens and states that these may not belong to mayensis, at that time belonging to $C$. nigriscens, although they show certain morphological dental characteristics suggesting a potential association. Hall (1981:63) still considered the record at Cañón del Zopilote, Guerrero as belonging to C. nigriscens mayensis. The analysis of the database shows that the only species of Cryptotis distributed in the state of Guerrero is $C$. goldmani $(n=35)$. Cañón del Zopilote is $30 \mathrm{~km}$ in a straight line from Omiltemi, the type locality of $C$. goldmani (Choate 1970). It is highly likely that the records classified as $C$. mayensis actually belong to C. goldmani, although confirmatory genetic analyses are required. Cryptotis mayensis is listed under the Special Protection category in NOM059-SEMARNAT-2010 (DOF 2019) and as Least Concern by IUCN (Cuarón et al. 2016).

The record of Pteronotus davyi in Baja California Sur is based on a single female (Woloszyn and Woloszyn 1982), but it could not be located in any of the four possible scientific collections where it might have been deposited: Universidad Autónoma de Baja California Sur, Centro de Investigaciones Biológicas del Noroeste, Colección Nacional de Mamíferos of the Instituto de Biología at Universidad Nacional Autónoma de México, and Zoological Collection of the Mammal Research Institute at the Polish Academy of Sciences (https://ibs.bialowieza.pl/en/scientific-collection/). The lack of records and the reference in the book by Woloszyn and Woloszyn (1982) describing that most of the organisms captured were released in situ suggest that this is the case of this specimen (Woloszyn and Woloszyn 1982; Jones 1983), thus making it impossible to confirm its correct identification. The analysis of specimens deposited in collections yielded 5,274 records from the databases of 37 national and international scientific collections corresponding to the genus Pteronotus from across its distribution; no other record for the Baja California peninsula of any of the four species of the genus distributed in México was found. The record of Pteronotus davyi that is closest to Baja California Sur is La Chinacatera, Sinaloa, located on the other side of the Gulf of California in the continental portion of México located $232 \mathrm{~km}$ away in a straight line (Figure 1B; Table 1). In the state of Sinaloa, 289 specimens of Pteronotus have been recorded. Bats have been collected across this region over 30 years, surveying more than 30 mines with bat colonies. In some cases, monthly follow-up of the colonies has been conducted in some mines (Segura-Trujillo 2014), and other research groups have carried out field surveys, with no records of the species in any such cases (Arnaud et al. 2012; Vanderplanck et al. 2016). The unique Mormoopid species present and abundant in the area is Mormoops megalophylla (Cortés-Calva et al. 2016).

Possible explanations are that $P$. davyi may have been misidentified as Mormoops; this seems rather unlikely given the dissimilar morphology; another scenario is that the specimen was captured across the Gulf of California by a hurricane. The data analysis shows no evidence or a valid record to confirm the presence of $P$. davyi in the Baja California peninsula, so this area should not be considered within the distribution range of this species. P. davyi is listed as Least Concern by the IUCN (Solari and Dávalos 2019).

The record of Marmosa sp. (López-Forment and Urbano 1977) can be assigned to Tlacuatzin sinaloe (Arcangeli et al. 2018) based on species with closest distribution. The record is based on the finding of a mandible fragment found in a pellet of a barn owl (Tyto alba), that is not deposited in any scientific collection. López-Forment and Urbano (1977:240) state that "It is impossible to accurately determine the species because it is the only fragment in our material is a mandible. If it were not for this circumstance, we would be 
inclined to believe that it belongs to Marmosa canescens, considering that this species reaches its northernmost distribution on the western coast." According to the distribution, the only species in the Marmosa complex is T. sinaloe, distributed along the Pacific coast from its border of Jalisco with Nayarit to Álamos, Sonora (Figure 1A). Álamos is the known locality of Tlacuatzin that is closest in straight-line to the Baja California Sur record, $393 \mathrm{~km}$ apart (Table 1), on the other side of the Gulf of California, which at this point has a width of $220 \mathrm{~km}$. This is a species of exclusively terrestrial habits; thus, if it had dispersed, it would have moved along the coast northward through the coast of Sonora and then south through the Baja California peninsula. The covering a distance between both localities is $1,149 \mathrm{~km}$ and crossing the Altar Desert - one of the most inhospitable landscapes in North America. This displacement may have occurred during the Pliocene, some 4 to 5 million years ago (Gastil et al. 1975) when the peninsula was still united to the continent. There is a record of a fossil marsupial (Pediomys sp.) in El Rosario, Baja California, which is common to localities in the central-western United States during the Mesozoic-Cretaceous period (Ferrusquía-Villafranca and Torres-Roldán 1980; Ferrusquía-Villafranca et al. 2010). The review of literature references and databases of 30 national and international museum collections shows that this is the only record of the Northern Grayish mouse opossum corresponding to the Baja California peninsula. In contrast, 123 records were found in Sinaloa and seven in Álamos, Sonora.

The likely logic explanation is that the Northern Grayish mouse opossum was predated and eaten by a Barn owl in Sinaloa, which then flew to the Baja California peninsula, regurgitated its mandible and been found into the pellet. When migrating, Tyto alba can travel between 20 and 1,000 $\mathrm{km}$, flying over the South Atlantic Ocean (Santillán et al. 2011; Audubon 2021). It has also been suggested that the Northern Grayish mouse opossum may have been carried in a box of fruit from the mainland and was subsequently consumed by T. alba once in the Baja California peninsula (Gardner and Cortés-Calva 1999). The incidentally introduction of a species is a common event in aquatic species, insects, and plants (Ramírez-Albores and Badano 2013; Mendoza-Alfaro and Koleff 2014). The previous explanations lead to consider that the Northern Gray mouse opossum is not currently distributed in the Baja California peninsula. Tlacuatzin sinaloe is listed (as T. canescens) under Least Concern category on the IUCN Red List (Martin 2017). Its recent taxonomic changes warrant a reassessment of its conservation status.

Type-locality records. Dipodomys gravipes was described from a locality $3 \mathrm{~km}$ west of Misión de Santo Domingo, Baja California (Huey 1925; Figure 1A) and is known only from the San Telmo plains to El Rosario de San Quintín, in the eastern portion of the Baja California peninsula, associated with desert coastal shrub vegetation in relatively flat areas with deep soils (Best 1983; Best and Lackey 1985; Patton and Álvarez-Castañeda 1999). When Huey (1925) collected the original specimen, there were two large colonies in the collection area and these were considered abundant until 1972, when the area started to be cleared for agriculture (Best 1983; Best and Lackey 1985). The last record dates back to 1986, although Tremor et al. (2019) possibly captured an individual of the species, but it is not confirmed. In addition, an analysis of the remaining optimal habitat for $D$. gravipes was conducted, where a small population may still exist in the wild (Cab-Sulub and Álvarez-Castañeda 2020). Dipodomys gravipes is listed as Extinct by NOM-059-SEMARNAT-2010 (DOF 2019) and as Critically Endangered (possibly extinct, D: Number of mature individuals lower than 1,000) by IUCN (Álvarez-Castañeda and Lacher 2018).

Oryzomys peninsulae is described from six specimens from Santa Anita, Baja California Sur (Thomas 1897; Figure 1A); it was last recorded in 1906 by Goldman (1951) in Santa Anita and San José del Cabo, Baja California Sur. Nelson (1922) considers that it is an introduced species that should be considered as O. couesi. Later, Carleton and Arroyo-Cabrales (2009) reviewed the status of this species and considered it to be valid.

At the beginning of the 1990s, Álvarez-Castañeda (1994) searched for the species and determined that tourist development in the Los Cabos region led to the drying-up of the Santa Anita stream, causing the loss of habitat for Oryzomys, and thus declared it as potentially extinct. Oryzomys peninsulae is listed as Extinct by NOM-059-SEMARNAT-2010 (DOF 2019) and as a Least Concern (as a subspecies of $O$. couesi) by IUCN (Linzey et al. 2016), if is validated O. peninsulae as a full species, it could change its risk category.

Peromyscus mekisturus has its type locality in Ciudad Serdán (Chalchicomula), Puebla, documented by Merriam (1898; Figure 1A) from a single specimen. Later, another specimen collected at Tehuacán, Puebla was identified as P. mekisturus (Hooper 1947); however, this second specimen may instead correspond to P. melanophrys, according to the analysis of Castañeda-Rico et al. (2014), where it is mentioned that this specimen was previously considered a member of the melanophrys species group (Hooper 1968; Hall 1981; Carleton 1989). Chalchicomula is surrounded by oat, barley, and chickpea crop fields and uncultivated land where pastures, agave, cacti, small oak trees, and thorny shrubs grow (Goldman 1951:237). Castro-Campillo et al. (2014) and Bradley et al. (2017) described this species as occupying a pine-oak forest microhabitat based on Goldman (1951). The Chalchicomula specimen was not collected by Goldman but was donated by a local inhabitant, so no reliable geographic record is available. P. mekisturus is listed a Threatened in NOM-059-SEMARNAT-2010 (DOF 2019) and as Critically Endangered in the IUCN Red List (possibly extinct) (B1ab (iii): distribution less than $100 \mathrm{~km}^{2}$. highly fragmented and with still declining populations (Álvarez-Castañeda 2018).

Peromyscus pembertoni collected in the San Pedro Nolasco Island, Sonora, was reported along with $P$. boylii glasselli, which was captured in a similar amount (Burt 
1932; Figure 1A). Subsequently, Lawlor (1983) sampled the island and captured $P$. boylii glasselli organisms but no $P$. pembertoni. Although collection efforts on the island have continued, no other P. pembertoni organisms have been captured (Álvarez-Castañeda and Cortés-Calva 1999; Álvarez-Castañeda and Ortega-Rubio 2003; Sergio Ticul AlvarezCastañeda, pers. comm.). The presence of $P$. boylii and the absence of $P$. pembertoni suggest that $P$. boylii probably replaced $P$. pembertoni due to strong island and interspecific competition (Lawlor 1971). P. pembertoni is listed as Extinct in both NOM-059-SEMARNAT-2010 (DOF 2019) and the IUCN Red List (Álvarez-Castañeda et al. 2017).

The type locality of the shrew Sorex sclateri in Tumbalá and San Antonio Buenavista, Chiapas, is known only from the specimens used in their original description (Merriam 1897; Carraway 2007; Figure 1A). S. sclateri is a unique species due to its large size relative to species of the genus Sorex, so it is easy to distinguish by a specialist. To note, the only record of the species dates back to approximately 125 years ago, and the area where it was recorded is today heavily deforested (Cruz 2017). Shrews are hard-to collect species; in fact, Cryptotis lacandonensis was recently described (Guevara et al. 2014b). However, specimens from this species were already collected four years before being described, and their distribution range was expanded (Lorenzo et al. 2019; Pérez et al. 2019). The circumstances around its collection and the reference of the presence of other Soricidae in tropical regions suggests that S. sclateri as currently extinct. S. sclateri is listed as Threatened in NOM-059-SEMARNAT-2010 (DOF 2019) and as Critically Endangered (B1ab (iii): Current range less than 5,000 km², severely fragmented and continuously declining) by IUCN (Cuarón and de Grammont 2018).

Sorex stizodon is described from a specimen collected in what is now the Huitepec Ecological Reserve, Chiapas, located on the outskirts of the city of San Cristobal de las Casas (Figure 1A). S. cristobalensis is also found within the range of S. stizodon (Jackson 1925; Matson and OrdóñezGarza 2017). Most of the soricidae species are very difficult to identify, but in this case, S. stizodon distinguishes easily because it has a unique character within the genus, i.e., the second unicuspid tooth is much larger than the first (Merriam 1895). S. cristobalensis was recently collected near its type locality, very close to the reference locality of S. stizodon (Guevara et al. 2014a). This confirms the presence of species of the genus Sorex in the region and the absence of S. stizodon, which can therefore be considered extinct. S. stizodon is listed as Threatened in NOM-059-SEMARNAT-2010 (DOF 2019) and as Critically Endangered (B1ab (iii): current range less than $5,000 \mathrm{~km}^{2}$, severely fragmented and continuously declining) by IUCN (Cuarón et al. 2018).

Tylomys bullaris is known from a single specimen collected at the Tuxtla Gutiérrez region, Chiapas (Merriam 1901; Figure 1A). Some authors have considered that this specimen is actually a juvenile of T. nudicaudus (Hall 1981; Espinoza and Martínez 2009), although it has very enlarged audi- tory bullae that allow its easy differentiation. The distribution range has rough physiography, so there are still areas with optimum habitats; however, the difficult access to this area, also affected by constant social conflicts (Castro 2007), hinders the study of the fauna. This set of variables produces an unclear picture of the status of the species, despite the lack of collection records in over 120 years. Tylomys bullaris is listed as Threatened in NOM-059-SEMARNAT-2010 (DOF 2019) and as Critically Endangered (Possibly Extinct; B1ab $(\mathrm{i}, \mathrm{ii}, \mathrm{iii}, \mathrm{iv}, \mathrm{v})+2 \mathrm{ab}(\mathrm{i}$, ii, iii, iv, v): distribution area less than $100 \mathrm{~km}^{2}$; severely fragmented; continuous decline of the area of occurrence and habitat occupation and quality; number of localities less than $50 \mathrm{~km} 2$ in a continuous decline in the area of occurrence and habitat occupation and quality) by IUCN (Álvarez-Castañeda and Castro-Arellano 2019a).

Tylomys tumbalensis has been recorded only from Tumbalá, Chiapas, with a single specimen that is a sub-adult male (Merriam 1901; Figure 1A). Some authors have considered that this specimen is actually a juvenile of $T$. nudicaudus (Hall 1981; Espinoza and Martínez 2009). T. tumbalensis has been recorded in areas outside its type locality, but no specimens supporting these identifications are available in these cases (Espinoza et al. 1998; 1999a; 1999b; Goodwin (1955)). Based on reviews of specimens of both species from collections and the literature, they are considered to have distinguishing characteristics, such as the length of the maxillary toothrow (Monroy-Gamboa et al. in press). For its part, Goodwin (1955) recorded a specimen collected in La Primavera, Guatemala, that is larger but shows the dental trait that characterizes the species, so that it could be the second locality of T. tumbalensis. The locality in Guatemala implies a distribution broader than the known range and the possible validity and permanence of the species. It is worth highlighting that the species of the genus Tylomys are strictly arboreal, making the collection method highly complicated; consequently, this genus is scarcely represented in scientific collections. The natural vegetation in the Tumbalá region has been cleared or transformed across large areas (Cruz 2017), thus reducing the habitat of Tylomys. Hence, the record of Goodwin (1955) is important for expanding the range of this genus, which may be present in other localities of Chiapas and Guatemala. It is currently listed as Special Protection in NOM-059-SEMARNAT-2010 (DOF 2019) and as Critically Endangered (Possibly Extinct; B1ab (iii, v): area of occurrence less than $100 \mathrm{~km}^{2}$, severely fragmented, area and number of mature individuals under continuous decline) by IUCN (Álvarez-Castañeda and Castro-Arellano 2019b).

\section{Discussion}

The erroneous location and misidentification of species individuals affect the species knowledge because they are assigned biological, ecological, and climatic habits to which the species are not actually linked. This results in the distortion of the environmental parameters to which these species are associated. 
Any records that are geographically separated from the known and confirmed distribution range lead to erroneous associations between species and parameters. This type of uncertainty modifies some of the parameters used to propose the potential areas of distribution of the species, leading to errors because they can significantly increase the range considering habitats that are not viable for the species (Morrone and Escalante 2016). As a result, these errors impact the risk classification of species because they may affect their geographic projection of species distribution when models are developed (Teta and D'Elía 2019). In the case studies outlined in the present study, the mentioned records show locations outside the known range of the species, over 200 km away, (e. g. Tlacuatzin sinaloae, LópezForment and Urbano 1977; Arcangeli et al. 2018), with intermediate areas and off-limit records showing climatic variables and vegetation types different from those of the habitat associated with the species.

The use of records without following due care can have a direct effect on the knowledge of Mexican biodiversity. This study showed that at least three of the species analyzed can be considered as extinct, directly affecting the number of species recorded in the country and, in at least four species, influencing to modify the biodiversity estimators at regional and state scales.

The absence of specimens in collections does not allow the revision of the material to clarify doubts. This highlights the curatorial importance of the data and the support of this information through the deposit of specimens in scientific collections, because they serve as a reference and help to resolve some identification discrepancies that may have been committed, through the reexamination and morphological measurement of the species and even be used with molecular techniques to clarify doubts such as the case of $P$. mekisturus (Castañeda-Rico et al. 2020).

The global analysis of data for these 12 species has several implications. The first regards aspects of taxonomy. In the case of the two species of Tylomys, their taxonomic validity is questionable (Hall 1981; Espinoza and Martínez 2009; Monroy-Gamboa et al. in press). In both cases, the type specimens are the only ones known and do not involve adult organisms, nor take into account the wide intraspecific morphological variation in the genus Tylomys (Monroy-Gamboa et al. in press); therefore, the possibility that these species are synonymous with $T$. nudicuaudus cannot be ruled out. Must be realized genetic studies to confirm and validate them.

The extinction of species is the second one. Currently, Oryzomys peninsulae (Álvarez-Castañeda 1994) and Peromyscus pembertoni (Álvarez-Castañeda et al. 2017) are deemed extinct. The status of Dipomys gravipes is indeterminate because it is listed as Extinct in NOM-059-SEMARNAT-2010 (DOF 2019), but there is a recent record (Tremor et al. 2019), which has not been corroborated with museum material or genetic data from samples (Cab-Sulub and
Álvarez-Castañeda 2020); therefore, more detailed studies should be conducted on these species in particular to achieve a related conclusion and a correct risk categorization thereof. This study revealed that three species - Peromyscus mekisturus, Sorex sclateri and Sorex stizodon - have not been recorded over at least 100 years of biological exploration trips in México; we even know that some of them have been surveyed through systematic sampling approaches with no positive findings (Susette S. Castañeda-Rico, pers. comm. for P. mekisturus). This fact, together with the modification of the original areas from which these species were recorded, supports the assumption that these three species have an high probability to be currently extinct.

The third fact is that there are between seven and nine mammal species recently described for México. These species are known to have restricted distribution areas, i.e., they are habitat specialists, thus increasing the possibility of extinction associated with changes in their habitat from natural phenomena such as fires or anthropic issues such as changes in land use and deforestation.

Implications for mammal conservation in México. The above considerations are sufficient to produce an impact at local, regional, and national levels because strong arguments are presented to modify the current known range of Ateles geoffroyi, Cryptotis mayensis, Pteronotus davyi and Tlacuatzin sinaloae, in addition to the likely extinction of the other group of species. One or several species are found within protected areas and thus included in the respective management plans; therefore, it is considered that some adaptations are necessary to reflect the current situation facing the probability that they do not occur in that regions.

Tylomys bullaris and T. nudicaudus have been considered present in other areas in addition to their known range. The current and available data are insufficient to confirm their presence. However, the possibility of their presence in habitats differing from their common range cannot be ruled out, for being species with unique requirements, little-known features that restrain our current understanding of their biology and ecology (Monroy-Gamboa et al. in press). It is recommended to carry out systematized surveys for the species of arboreal habits, using ad hoc field methodologies that allow to know their biology and thus determine their distribution and current risk status.

\section{Acknowledgements}

Thanks to S. T. Álvarez-Castañeda, C. A. Segura-Trujillo, associated editor and anonymous reviewers for their comments and suggestions to improve this manuscript. To J. P. GalloReynoso for the monkeys data from Guerrero. To S. S. Castañeda-Rico for the Puebla deermouse data. To. M. E. Sánchez for the English translation. To Comisión Nacional de Ciencia y Tecnología (CONACyT) for the postdoctoral fellowship at Centro de Investigaciones Biológicas del Noroeste, S. C. (CVU 206047). 


\section{Literature Cited}

Álvarez, T. 1963. The recent mammals of Tamaulipas, Mexico. University of Kansas Publications. Museum of Natural History 14:363-473.

Álvarez-Castañeda, S. T. 1994. Current status of the rice rat, Oryzomys couesi peninsularis. The Southwestern Naturalist 39:99-100.

Álvarez-Castañeda, S.T. 2018. Peromyscus mekisturus. The IUCN Red List of Threatened Species 2018:e.T16675A22362990.

Álvarez-Castañeda, S. T., and I. Castro-Arellano. 2019a. Tylomys bullaris. The IUCN Red List of Threatened Species 2019:e. T22570A22340265.

Álvarez-Castañeda, S. T., and I. Castro-Arellano. 2019a. Tylomys tumbalensis. The IUCN Red List of Threatened Species 2019:e. T22575A22340781.

Álvarez-Castañeda, S. T., I. Castro-Arellano, T. Lacher, E. Vázquez, and J. Arroyo-Cabrales. 2017. Peromyscus pembertoni. The IUCN Red List of Threatened Species 2017:e. T16645A22361389.

Álvarez-Castañeda, S. T., and P. Cortés-Calva. 1999. Familia Muridae. Pp. 445-566, in Mamíferos del noroeste de México (Álvarez-Castañeda, S. T., and J. L. Patton, eds.). Centro de Investigaciones Biológicas del Noroeste, S. C. La Paz, México.

Álvarez-Castañeda, S. T., and T. Lacher. 2018. Dipodomys gravipes. The IUCN Red List of Threatened Species 2018:e. T6676A22227742.

Álvarez-Castañeda, S. T., and A. Ortega-Rubio. 2003. Current status of rodents on islands in the Sea of Cortez, Mexico. Biological Conservation 109:157-163.

Arcangel, J., J. E. Light, and F. A. Cervantes. 2018. Molecular and morphological evidence of the diversification in the gray mouse opossum, Tlacuatzin canescens (Didelphimorphia), with description of a new species. Journal of Mammalogy 99:138-158.

Arnaud, G., S. Álvarez-Cárdenas, and P. Cortés-Calva. 2012. Mamíferos de la Reserva de la Biosfera Sierra de la Laguna. Pp. 145-161, in Evaluación de la Reserva de la Biosfera Sierra La Laguna, Baja California Sur: Avances y Retos (Ortega-Rubio, A., M. Lagunas-Vázques, and L. F. Beltrán-Morales, eds.). Centro de Investigaciones Biológicas del Noroeste, S. C. La Paz, México.

Audubon. 2021. Guía de aves de América del Norte. National Audubon Society. https://www.audubon.org/bird-guide 31/01/2021. Consulted on19 February 2021.

BEst, T. L. 1983. Morphologic variation in the San Quintin kangaroo rat (Dipodomys gravipes Huey 1925). American Midland Naturalist 109:409-413.

Best, T. L., AND J. A. Lackey. 1985. Dipodomys gravipes. Mammalian Species 236:1-4.

Bradley, R. D, N. Ordóñez-Garza, and L. Bradley. 2017. Peromyscus mekisturus. Pp. 384, in Handbook of the Mammals of the World, Vol. 7, Rodents II (D. E. Wilson, T. E. Leacher, Jr., and R. A. Mittermeier, eds.). Lynx Edicions. Barcelona, Spain.

BURT, W.H. 1932. Description of heretofore unknown mammals from Island in the Gulf of California, Mexico. Transactions of the San Diego Society of Natural History 7:161-182.

Cab-Sulub, L., and S. T. Álvarez-Castañeda. 2020. Analysis of the remaining habitat of an endemic species rediscovered. Mammalian Biology 100:307-314.

Carleton, M. D. 1989. Systematic and evolution. Pp. 7-141, in Advances in the study of Peromyscus (Rodentia) (Kirkland,
G L., and J. N. Layne, eds.). Texas Tech University Press. Lubbock, U.S.A.

Carleton, M. D., and J. Arroyo-Cabrales. 2009. Review of the Oryzomys couesi complex (Rodentia: Cricetidae: Sigmodontinae) in western Mexico. Pp. 93-127, in Systematic Mammalogy: contributions in honor of Guy G. Musser (Voss. R. S., and M. D. Carleton, eds.). Bulletin of the American Museum of Natural History 331:1-450.

Carraway, L. N. 2007. Shrews (Eulipotyphla: Soricidae) of Mexico. Monographs of the Western North American Naturalist 3:1-91.

Castañeda-Rico, S., L. León-Paniagua, C. W. Edwards, and J. E. MALDONADO. 2020. Ancient DNA from museum specimens and next generation sequencing help resolve the controversial evolutionary history of the Critically Endangered Puebla Deer Mouse. Frontiers in Ecology and Evolution 8:94.

Castañeda-Rico, S., L. León-Paniagua, E. Vázquez-Domínguez, and A. G. Navarro-Sigüenza. 2014. Evolutionary diversification and speciation in rodents of the Mexican lowlands: the Peromyscus melanophrys species group. Molecular Phylogenetics and Evolution 70:454-463

CASTRO, J. E. 2007. El estudio interdisciplinario de los conflictos por el agua en el medio urbano: una contribución desde la sociología. Cuadernos del Cendes 24:21-46.

Castro-Campillo, A., H. Martínez-Paz, and J. Ramírez-Pulido. 2014. Peromyscus mekisturus Merriam, 1898. Pp. 751 , in Los mamíferos silvestres de México (Ceballos, G., and G. Oliva, eds.). Johns Hopkins University Press. Baltimore, U.S.A.

Choate, J. R. 1970. Systematics and zoography of Middle American shrews of the genus Cryptotis. University of Kansas Publication. Museum of Natural History 19:195-317.

Cook, J. A., AND J. LIGHT. 2019. The emerging role of mammal collections in $21^{\text {st }}$ century mammalogy. Journal of Mammalogy 10:733-750.

Cortés-Calva, P., A. Gutiérrez-Ramos, M. de la Paz-Cuevas, C. A. Segura-Trujillo, E. Aguilera-Miller, E. Rios, and S. T. ÁlvarezCAStAÑEDA. 2016. Mamíferos de Baja California Sur: Actualidad y perspectivas. Pp. 91-128, in (Briones-Salas, M., Y. HortelanoMoncada, G. Magaña-Cota, G. Sánchez-Rojas, and J. E. SosaEscalante, eds.). Riqueza y conservación de los mamíferos en México a nivel estatal. Vol. I. IB-UNAM/AMMAC/UG. Ciudad de México, México.

Cortes-Ortiz, L., D. Solano-Rojas, M. Rosales-Meda, K. Williams-Guillén, P. G. Méndez-Carvajal, L. K. Marsh, D. Canales-Espinosa, and R. A. Mittermeier. 2021. Ateles geoffroyi (amended version of 2020 assessment). The IUCN Red List of Threatened Species 2021: e.T2279A191688782.

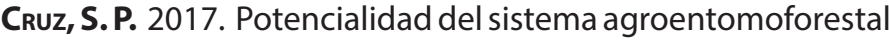
en Chiapas. Tesis de Maestría. Universidad Autónoma Chapingo. Texcoco, México.

Cuarón, A. D., and P. C. de Grammont. 2018. Sorex sclateri. The IUCN Red List of Threatened Species 2018:e. T20394A22316927.

Cuarón, A. D., P. C. de Grammont, and J. Matson. 2018. Sorex stizodon. The IUCN Red List of Threatened Species 2018:e. T20395A22316681.

Cuarón, A. D., P. C. de Grammont, N. Woodman, and J. Matson. 2016. Cryptotis mayensis. The IUCN Red List of Threatened Species 2016:eT136488A22284558. 
DOF. Diario Oficial de la Federación. 2019. Modificación del Anexo Normativo III, Lista de especies en riesgo de la Norma Oficial Mexicana NOM-059-SEMARNAT-2010, Protección ambiental-Especies nativas de México de flora y fauna silvestres-Categorías de riesgo y especificaciones para su inclusión, exclusión o cambio-Lista de especies en riesgo. Diario Oficial de la Federación. Ciudad de México, México.

Espinoza, E. 2005. Tylomys tumbalensis Merriam, 1901. Pp. 808-809, in Mamíferos silvestres de México (Ceballos, G., and G. Oliva, coords.). Fondo de Cultura Económica, Comisión Nacional para el Conocimiento y Uso de la Biodiversidad. Distrito Federal, México.

Espinoza, M. E., A. Anzures, And E. Cruz. 1998. Mamíferos de la Reserva de la Biosfera "El Triunfo", Chiapas. Revista Mexicana de Mastozoología 3:79-94.

Espinoza, E. E., And M. Martínez. 2009. Análisis morfológico y morfométrico de ratas arborícolas del género Tylomys. Pp. 43-54, in 60 años de la Colección Nacional de Mamíferos del Instituto de Biología, UNAM. Aportaciones al conocimiento y conservación de los mamíferos mexicanos (Cervantes-Reza, F. A., Y. HortelanoMoncada, and J. Vargas-Cuenca, comps.). Universidad Nacional Autónoma de México. Distrito Federal, México.

Espinoza, E. E., H. Núñez, P. González, R. Luna, M. A. Altamirano, E. Cruz, G. Cartas, and C. Guichard. 1999a. Listado preliminar de los vertebrados terrestres de la Reserva de la Biosfera "El Triunfo", Chiapas. Publicaciones Especiales del Instituto de Historia Natural 1:1-38.

Espinoza, E., H. Núñez, P. González, R. Luna, D. Navarro, E. CRUZ, and C. GuichaRD. 1999b. Lista preliminar de los vertebrados terrestres de la selva "El Ocote", Chiapas. Publicaciones especiales del Instituto de Historia Natural 2:1-40.

Ferrusquía-Villafranca, I., J. Arroyo-Cabrales, E. MartínezHernández, J. Gama-Castro, J. Ruiz-González, O. J. Polaco, and E. Johnson. 2010. Pleistocene mammals of Mexico: A critical review of regional chronofaunas, climate change response and biogeographic provinciality. Quaternary International 217:53-104.

Ferrusquía-Villafranca, I., ANd V. Torres-Roldán. 1980. El registro de mamíferos terrestres del Mesozoico y Cenozoico de Baja California. UNAM. Instituto de Geología, Revista 4:56-62.

Funk, V. A. 2018. Collections-based science in the 21 st century. Journal of Systematics and Evolution 56:175-193.

Gardner, A., And P. Cortés-Calva. 1999. Didelphidae. Pp. 29-37, in Mamíferos del Noroeste de México (Álvarez-Castañeda, S. T., and J. L. Patton, eds.). Centro de Investigaciones Biológicas del Noroeste. La Paz, México.

Gastil, G. R., R. P. Philuips, And E. C. Aluison. 1975. Reconnaissance geology of the State of Baja California. Memoir 140. The Geological Society of America, Inc. Boulder, U.S.A.

GBIF. 2021. Global Biodiversity Information Facility. https:// www.gbif.org/. Consulted on 17 March 2021.

Goldman, E. A. 1951. Biological investigations in Mexico. Smithsonian Miscellaneous Collection 115:1-476.

González-Zamora, A., V. Arroyo-Rodríguez, Ó. M. Chaves, S. Sánchez-López, K. E. Stoner, and P. Riba-Hernández. 2009. Diet of spider monkeys (Ateles geoffroyi) in Mesoamerica: current knowledge and future directions. American Journal of Primatology 71:8-20.
Goodwin, G. G. 1955. New tree-climbing rats from Mexico and Colombia. American Museum Novitates, American Museum of Natural History 1738:1-5.

Goodwin, G. G. 1969. Mammals from the state of Oaxaca, Mexico, in the American Museum of Natural History. Bulletin of the American Museum of Natural History 141:1-270.

Graham, C. H., S. Ferrier, F. Huettman, C. Moritz, and A. T. Peterson. 2004. New developments in museum-based informatics and applications in biodiversity analysis. Trends in Ecology and Evolution 19:497-503.

Guevara, L., C. Lorenzo, S. Ortega-García, and V. SánchezCordero. 2014a. Noteworthy records of an endemic shrew from Mexico (Mammalia, Soricomorpha, Crytotis griseoventris), with comments on taxonomy. Mammalia 78:405-408.

Guevara, L., V. Sánchez-Cordero, L. León-Paniagua, and N. Woodman. 2014b. A new species of small-eared shrew (Mammalia, Eulipotyphla, Cryptotis) from the Lacandona rain forest, Mexico. Journal of Mammalogy 95:739-753.

Hall, E. R. 1981. The mammals of North America. John Wiley and Sons. New York, U.S.A.

Hooper, E. T. 1947. Notes on Mexican Mammals. Journal of Mammalogy 28:40-57.

Hooper, E. T. 1968. Classification. Pp 27-74, in Biology of Peromyscus (Rodentia) (King, J. A., ed.). Special Publication of the American Society of Mammalogists 2:1-593.

HueY, L. M. 1925. Two new kangaroo rats of the genes Dipodomys from lower California. Proceedings of the Biological society of Washington 38:83-85.

JACKSON, H. H. T. 1925. The Sorex arcticus and Sorex arcticus cinereus of Kerr. Journal of Mammalogy 6:55-56.

Jones, C. 1983. Review. Journal of Mammalogy 64:728-729.

Kellogg, R., and E. A. Goldman. 1944. Review of the spider monkeys. Proceedings of the United States National Museum 96:1-45.

LawLOR, T. E. 1971. Evolution of Peromyscus on Northern Island in the Gulf of California, Mexico. Transactions of the San Diego Society of Natural History 16:91-124.

LAwLOR, T. E. 1983. The mammals. Pp. 265-289, in Island biogeography in the Sea of Cortez (Case, T. J., and M. L. Cody, eds.). University of California Press. Berkeley, U.S.A.

Linzey, A. V., R. Timm, N. Woodman, J. Matson, and R. Samudio. 2016. Oryzomys couesi (errata version published in 2017). The IUCN Red List of Threatened Species 2016:e. T15592A115128044.

López-Forment, W., and G. Urbano. 1977. Restos de pequeños mamíferos recuperados en regurgitaciones de lechuza, Tyto alba, en México. Anales del Instituto de Biología, Universidad Nacional Autónoma de México, Serie Zoología 48:231-242.

Lorenzo, C., J. Bolaños-Citalán, D. Navarrete-Gutiérrez, J. A. Pérez-López, and L. Guevara. 2019. In search of shrews of Chiapas: analysis of their distribution and conservation. Therya 10:121-129.

Martin, G. M. 2017. Tlacuatzin canescens. The IUCN Red List of Threatened Species 2017:e.T12813A22177633.

Matson, J. O., and N. Ordóñez-Garza. 2017. The taxonomic status of Long-tailed shrews (Mammalia: genus Sorex) from Nuclear Central America. Zootaxa 4236:461-483.

Mendoza-Alfaro, R. E., And P. Koleff (eds.). 2014. Especies acuáticas invasoras de México. CONABIO. Ciudad de México, México. 
Merriam, C. H. 1895. Synopsis of the American shrews of the genus Sorex. North American Fauna 10:57-124.

Merriam, C. H. 1897. Notes on the chipmunks of the genus Eutamias occurring west of the east base of the CascadeSierra system, with descriptions of new forms. Proceedings of the Biological Society of Washington 11:189-212.

Merriam, C. H. 1898. Description of twenty new species and new subgenus of Peromyscus from Mexico and Guatemala. Proceedings of the Biological Society of Washington 12:115-125.

Merriam, C. H. 1901. Seven new mammals from Mexico, including a new genus of rodents. Proceedings of the Washington Academy of Sciences 3:559-563.

Monroy-Gamboa, A. G., S. T. Álvarez-Castañeda, and A. L. TrujanoÁlvarez. En prensa. Tylomys nudicaudus. Mammalian Species. Morrone, J. J., AND T. Escalante. 2016. Introducción a la biogeografía. Universidad Nacional Autónoma de México. Ciudad de México, México.

Nelson, E. W. 1922. Lower California and its natural resources. National Academy of Sciences, First Memories 16:1-194.

Patton, J. L., and S. T. ÁlvarezCastañeda. 1999. Family Heteromyidae. Pp. 351-443, in Mamíferos del Noroeste Mexicano (Álvarez-Castañeda, S. T., and J. L. Patton, eds.). Centro de Investigaciones Biológicas del Noroeste, S. C. La Paz, México.

Pérez, S. G., M. R. Jolón, J. E. Mérida, And A. J. Andino-Madrid. 2019. First record of the shrew Cryptotis lacandonensis (Eulipotyphla: Soricidae) for Guatemala. Therya 10:187-193.

QGIS. 2018. QGis 3.8.3 www.qgis.org

Ramírez-Albores, J. E., and E. I. Badano. 2013. Perspectiva histórica, sociocultural y ecológica de una invasión biológica: el caso del pirúl (Schinus molle L., Anacardiaceae) en México. Boletín de la red Latinoamericana para el estudio de especies invasoras 3:4-15.

Ramírez-Pulido, J., and C. Sánchez-Hernández. 1972. Regurgitaciones de lechuza, procedentes de la cueva del Cañón del Zopilote, Guerrero, México. Revista de la Sociedad Mexicana de Historia Natural 33:107-112.

Reyes-Álvarez, F. Y. C., ANd G. Guerrero-Gómez. 2014. Geometrías de la imaginación e iconografía de Guerrero. Conaculta. Distrito Federal, México.

Santillán, M. A., J. de la Cruz-Martínez, A. Travaini, and P. A. Gandinı. 2011. Presencia de la lechuza de campanario (Tyto alba) en el océano Atlántico Sur. Hornero 26:159-161.

Segura-Trujillo, C. A. 2014. Dieta y gremios tróficos de los murciélagos depredadores de artrópodos de Norte y Centro América. Tesis de Maestría. Centro de Investigaciones Biológicas del Noroeste, S. C. La Paz, México.

Soları, S., And L. Dávalos. 2019. Pterontus davyi. The IUCN Red List of Threatened Species 2019:e.T18705A22077399.

Teta, P., And G. D'Elía. 2019. The last known with the smallest ranges: analyzing the patterns of occurrence and conservation of South American rodents known only from their type localities. Therya 10:271-278.

Tномаs, O. 1897. Description of new bats and rodents from America. Annals and Magazine of natural History, series 6 20:544-553.

Tremor, S., S. Vanderplank, and E. Mellink. 2019. The San Quintín Kangaroo rat is not extinct. Bulletin Southern California Academy of Sciences 118:71-75.
Vanderplank, S., B. T. Wilder, and E. Ezcurra (comps.). 2016. Arroyo La Junta. Una joya de biodiversidad en la Reserva de la Biosfera Sierra de La Laguna. Botanical Research Institute of Texas, Next Generation Sonoran Desert Researchers and UC MEXUS. California, U.S.A.

VILLA, R. B. 1958. El mono araña (Ateles geoffroyi) encontrado en la costa de Jalisco y en la región central de Tamaulipas. Anales del Instituto de Biología XXVIII:345-347.

Woloszyn B., And D. Woloszyn. 1982. Los mamíferos de la Sierra de La Laguna, Baja California Sur. Comisión Nacional de Ciencia y Tecnología. Distrito Federal, México.

Associated editor: Jorge Servin

Submitted: June 5, 2021; Reviewed: June 6, 2021

Accepted: June 7, 2021; Published on line: June 8, 2021. 